\title{
Two New Antiinflammatory Triterpene Saponins from the Egyptian Medicinal Food Black Cumin (Seeds of Nigella sativa)
}

\author{
Mohamed Elbandy, ${ }^{\ddagger}$, Ok-Hwa Kang, ${ }^{\ddagger}$ Dong-Yeul Kwon, ${ }^{\ddagger}$ and Jung-Rae Rho ${ }^{\dagger *}$ \\ ${ }^{\dagger}$ Deparment of Oceanograph, Kunsan National Lnwersity, Jeonbuk 573-701, Korea. ${ }^{\circ}$ E-mail: jrrhorakunsan.ackr \\ ${ }^{\ddagger}$ College of Pharmacy and Wonkitang-Oriental Medicines Research Institute. Honkwang University. \\ Iksan, Jeonbuk 570-749, Korea \\ Deparment of Food Sciences and Technologv. Faculty of Environmental Agricultural Sciences, \\ Sitez Canal Linversity, Elarish, North Sinai, Egvpt \\ Received June 24, 2009, Accepted Julv 02, 2009
}

\begin{abstract}
An extensive phytochenical investigation of the polar fractions of a methanolic extract of Egyptian medicinal food. black cunin (seeds of ivella sativa L.) led to the isolation of two new triterpene saponins, named sativosides $A$ and $\mathrm{B}$ (1-2), along with four known saponins (3-6). Sativoside $\mathrm{A}(\mathbf{1})$ is the first example of saponins containing 18 -ene triterpene aglycon not only in this Nigella genus but also in the family Ranunculaceae. The structure of the new saponins was elucidated mainly by a combination of 1D and 2D NMR data, together with HRFABMS and acid hydrolysis. Three compounds (1-3) showed the significant inhibition effect of phorbol 12-myristate 13-acetate (PMA) plus calcium ionophore A23187-induced production of IL-6 in a human mast cell (HMC-1) line.
\end{abstract}

Key Words: Nigella sativa L, Sativosides A and B, 18-Ene triterpene. Pro-inflammatory cytokine

\section{Introduction}

The seeds of Nigella sativa $\mathrm{L}$ (black cumin) are an amazing medicinal food. In Arabic countries it is called Al-Haba-ElSauda or Habat-Al-Baraka. Nigella sativa is an anmual dicotyledon herbaceous plant of the family Ranunculaceae. It grows in Middle east area and it is believed to be indigenous to the Arabic countries and the Mediterranean region but has been cultivated in other parts of the world including northern Africa and parts of Asia. ${ }^{1-2}$ For thousands of years. black cumin has been used in many Asian, Middle Eastern and Far Eastem countries as an additive in spices. ${ }^{3}$ flavored and aromatic substances. ${ }^{4}$ and food preservative. ${ }^{1}$ These seeds are commonly eaten alone or in combination with honey and it is also used as condiments in many food preparations (curries. pastries. bread and Mediterranean cheese) ${ }^{5-6}$ In addition. hot aqueous extract of seeds is also widely used in Egypt as warm drink. $N$. sativa extract can be used in the preservation of food and prevention of food poisoning. It has long been used in traditional folk medicine as a protective and health remedy for a wide range of illnesses. including headache. bronchial asthma, abdominal pains, hypertension. gastrointestinal problems. diarrhea and rheumatism. especially in the Southeast Asia and Middle East. ${ }^{8}$ Black cumin is one of the most extensively pharmacologically studied medicinal foods. Many biological studies on the effect of N. sativa seed extract or its active compounds including antioxidant, antiinflammatory anticarcinogenic. antidiabetic antiulcer antiparasitic, antihistaminic, antiviral. antifungal, antibacterial. antihelminthic and immunomodulatory effects have been reported. The seeds have very rich and diverse chemicals which contain fixed and volatile oils. proteins. amino acids. alkaloids and saponins. ${ }^{5.9-16}$ Several constituents were characterized in volatile oil, including carvone, carvene. $\alpha$-pinene, $p$-cymene. and the crystalline active principle. nigellone. Moreover. thymoquinone. dithymoquinone. thy molydroquinone, and thy mol are the pharmacologicaly active conponents in the volatile oil. Two indazole alkaloids. nigellicine and nigellidine. an isoquinoline alkaloid. nigellimine and its $\mathrm{N}$-oxide. ${ }^{\text {s.lo }}$ and eight new dolabellane-type diterpene alkaloids, nigellamines $\mathrm{A}_{3}, \mathrm{~A}_{2}, \mathrm{~B}_{1}, \mathrm{~B}_{2}, \mathrm{~A}_{2}, \mathrm{~A}_{4}, \mathrm{~A}_{5}$. and $C$ were isolated from black cunin. ${ }^{11.32}$ Four known hedragenin saponins have been previously reported from the seeds of N. sativa. two monodesmosidic glycosides with disaccharide ( $\alpha$-hederen) and trisaclaride chains at $\mathrm{C}-3$ of the aglycon through an ether bond. ${ }^{13}$ in addition to two bisdesmosidic saponins with two sugar chains at $\mathrm{C}-3$ and $\mathrm{C}-28$ of the hedragenin triterpene. ${ }^{14}$

The polar extracts of the seeds of $\mathrm{N}$. sativa showed many biological activities. including anticancer, antiulcer, antimicrobial. anti-inflaummatory and spasnolytic effects ${ }^{5.9110}$ and saponins were the main chemical constituents in the polar fractions of our methanolic extract. Moreover. the inportance of saponins is increasing in food cosmetics. and pharmaceutical sectors because of their physicochentical (surfactant) properties and mounting evidence on their biological activity. ${ }^{15-1 ? \text { ? }}$ These observations prompted us to continue in our research aimed at finding biologically active and/or novel saponins from plant origin. ${ }^{\text {18-23 }}$ Recently. we investigated the suppression effect of the production of cytokine interleukin (IL)- 6 in human mast cell (HMC-1) on the methanolic extract of the seeds of $N$. sativa. which may contribute to the treatment of astlumatic inflammation. Through bioactivity and ${ }^{1} \mathrm{H}$ NMR monitoring guided fractionation of the methanolic extract of the seeds of N. sativa. six triterpene glycosides were isolated composed of two new compounds. sativosides A (1) and B (2) and four known ones. Herein, we report the isolation and structure elucidation of two new triterpene saponins and the evaluation of inhibition effect of the isolated compounds on phorbol 12-myristate 13acetate (PMA) plus calciunt ionophore A23187-induced production of cytokine IL-6 in HMC-1 line. 


\section{Experimental}

Genemal methods. Optical rotations were measured on a JASCO P-1010 digital polarimeter. IR spectra were recorded on a JASCO FT/IR-4100 spectrometer. The ID and 2D NMR spectra were obtained on a Varian VNMRS 500 spectrometer working at $500 \mathrm{MHz}$ for ${ }^{1} \mathrm{H}$ and $125 \mathrm{MHz}$ for ${ }^{13} \mathrm{C}$. All NMR chemical shifts were referenced to $\mathrm{CD}_{3} \mathrm{OD}$ at $\delta_{\mathrm{H}} 3.30$ and $\delta_{c}$ 49.0 as an internal standard. HRFAB mass spectra were acquired with a Jeol JMS-700. supported by Korea basic science

Table 1. NMR Spectral Data of the Aglycon Portion of sativosides A (1) and $\mathrm{B}(2)$ in $\mathrm{CD}_{3} \mathrm{OD}$

\begin{tabular}{|c|c|c|c|c|}
\hline \multirow{2}{*}{110} & \multicolumn{2}{|l|}{1} & \multicolumn{2}{|l|}{2} \\
\hline & $\ddot{\partial}_{\mathrm{H}}$ & $\partial_{c}$ & $\delta_{H}$ & $\delta_{C}$ \\
\hline $\begin{array}{l}\text { la } \\
\text { lb }\end{array}$ & $\begin{array}{l}0.93^{\sigma} \\
1.73^{\sigma}\end{array}$ & $40.1,1$ & $\begin{array}{l}1.07^{a} \\
1.68^{a}\end{array}$ & $39.5, t$ \\
\hline $\begin{array}{l}2 \mathrm{a} \\
2 \mathrm{~b}\end{array}$ & $\begin{array}{l}1.76^{\sigma} \\
1.89^{\circ}\end{array}$ & $26.8, t$ & $\begin{array}{l}1.77^{a} \\
1.91^{\circ}\end{array}$ & $26.0, t$ \\
\hline $\begin{array}{l}3 \\
4\end{array}$ & $3.61^{\sigma}$ & $\begin{array}{l}82.3, d \\
44,1,5\end{array}$ & $3.87^{a}$ & $\begin{array}{l}82.1, d \\
56.3, s\end{array}$ \\
\hline 5 & $1.21^{\sigma}$ & $48.6, d$ & $1.32^{\circ}$ & $49.4, d$ \\
\hline $\begin{array}{l}6 \mathrm{a} \\
6 \mathrm{~b}\end{array}$ & $\begin{array}{l}1.36^{\sigma} \\
1.45^{\sigma}\end{array}$ & $18.7, t$ & $\begin{array}{l}0.89^{a} \\
1.48^{a}\end{array}$ & $21.4, t$ \\
\hline $\begin{array}{l}7 \mathrm{a} \\
7 \mathrm{~b}\end{array}$ & $\begin{array}{l}1.43^{\sigma} \\
-\end{array}$ & $35.2, t$ & $\begin{array}{l}1.22^{\circ} \\
1.50^{\circ}\end{array}$ & $33.3, t$ \\
\hline 8 & & $41.9, s$ & & $41.0, s$ \\
\hline $\begin{array}{l}9 \\
10\end{array}$ & $1.35^{\alpha x}$ & $\begin{array}{l}52.6, d \\
37.8, s\end{array}$ & $1.68^{4}$ & $\begin{array}{l}48.6, d \\
37.0, s\end{array}$ \\
\hline $\begin{array}{l}11 \mathrm{a} \\
11 \mathrm{~b}\end{array}$ & $\begin{array}{l}1.33^{\sigma} \\
1.58^{\sigma}\end{array}$ & $22.2, t$ & $\begin{array}{l}1.91^{a} \\
-\end{array}$ & $24.5, t$ \\
\hline 12 & $\begin{array}{l}1.25^{\sigma} \\
1.57^{\sigma}\end{array}$ & $27.1,1$ & $5.25(1 \mathrm{H}, \mathrm{bs})$ & $123.5, d$ \\
\hline $\begin{array}{l}13 \\
14\end{array}$ & $2.28(1 \mathrm{H}, \mathrm{d}, 11.7)$ & $\begin{array}{l}42.3, d \\
43.7,5\end{array}$ & & $\begin{array}{l}144.9, s \\
43.0, s\end{array}$ \\
\hline $\begin{array}{l}15 a \\
15 b\end{array}$ & $\begin{array}{l}1.18^{a} \\
1.70^{a}\end{array}$ & $30.5, t$ & $\begin{array}{l}1.05^{a} \\
1.75^{a}\end{array}$ & $28.9, t$ \\
\hline $\begin{array}{l}16 a \\
16 b\end{array}$ & $\begin{array}{l}1.60^{a} \\
2.02^{a}\end{array}$ & $34.2, t$ & $\begin{array}{l}1.69^{4} \\
2.04^{4}\end{array}$ & $24.0 . t$ \\
\hline 17 & & $49.9,5$ & & $48.0 . s$ \\
\hline 18 & & $138.3, s$ & $2.85(1 \mathrm{H}, \mathrm{dd}, 4.1,18.3)$ & $42.8, d$ \\
\hline 19 & $5.14(1 \mathrm{H}, \mathrm{bs})$ & $1340, d$ & $\begin{array}{l}1.13^{4} \\
1.70^{4}\end{array}$ & $47.2, t$ \\
\hline 20) & & $33.0,5$ & & $31.6, s$ \\
\hline $\begin{array}{l}21 \mathrm{a} \\
2 \mathrm{lb}\end{array}$ & $\begin{array}{l}1.33^{\sigma} \\
1.44^{\sigma}\end{array}$ & $34.5, t$ & $\begin{array}{l}1.22^{a} \\
1.37^{a}\end{array}$ & $34.9, t$ \\
\hline $\begin{array}{l}22 \mathrm{a} \\
22 \mathrm{~b}\end{array}$ & $\begin{array}{l}1.45^{\alpha} \\
2.22^{\sigma}\end{array}$ & $34.6, t$ & $\begin{array}{l}1.60^{\circ} \\
1.70^{\circ}\end{array}$ & $33.2, t$ \\
\hline $2 \hat{3}$ & $\begin{array}{l}3.33^{\alpha} \\
3.51^{\sigma}\end{array}$ & $64,6, t$ & $9.5(1 \mathrm{H}, \mathrm{bs})$ & $209.3, d$ \\
\hline 24 & $0.68(3 \mathrm{H}, \mathrm{s})$ & $13.7,9$ & $1.13(3 \mathrm{H}, \mathrm{s})$ & $10.8, q$ \\
\hline 25 & $0.93(3 \mathrm{H}, \mathrm{s})$ & $17.8,9$ & $1.00(3 \mathrm{H}, \mathrm{s})$ & $16.2,9$ \\
\hline 26 & $1.01(3 \mathrm{H}, \mathrm{s})$ & $16.8, q$ & $0.79(3 \mathrm{H}, \mathrm{s})$ & $17.8,9$ \\
\hline 27 & $0.81(3 \mathrm{H}, \mathrm{s})$ & $15.6, q$ & $1.17(3 \mathrm{H}, \mathrm{s})$ & $26.3, q$ \\
\hline 28 & & $177.0, \mathrm{~s}$ & & $178.2, s$ \\
\hline 29 & $0.99(3 \mathrm{H}, \mathrm{s})$ & $30.9,9$ & $0.91(3 \mathrm{H}, \mathrm{s})$ & $33.5,9$ \\
\hline 30 & $0.97(3 \mathrm{H}, \mathrm{s})$ & $29.4,9$ & $0.94(3 \mathrm{H}, \mathrm{s})$ & $24.1,9$ \\
\hline
\end{tabular}

"Overlapped with other signals, $q=\mathrm{CH}_{3}, t=\mathrm{CH}_{s}, d=\mathrm{CH}, s=\mathrm{C}$.
Institute Daegu Center. HPLC was performed with a Varian RI detector using the YMC ODS-A column ( $10 \times 250 \mathrm{~mm}$. \$-5 $\mu \mathrm{m})$ and the Varian polaris $\mathrm{NH}_{2}$ column $(4.6 \times 250 \mathrm{~mm}, \mathrm{~S}-5 \mu \mathrm{m})$. All solvents were distilled prior to use and authentic sugars were purchased from Fluka and Sigma.

Plant material. Seeds of $N$. sativa were purchased from an herbal market in Elarish. Egypt in May 2008. The voucher specinen is at the Department of Food Sciences and Teclurology, Faculty of Environmental Agricultural Sciences, Suez Canal University

Extraction and isolation. The dried and powdered seeds of 1. sativa $(500 \mathrm{~g})$ were extracted successively with hexane $(3 \times$ $1000 \mathrm{~mL} .122 \mathrm{~g}), \mathrm{CH}_{2} \mathrm{Cl}_{2}(3 \times 1000 \mathrm{~mL}, 18.7 \mathrm{~g})$. EtOAc $(3 \times$ $1000 \mathrm{~mL} .12 .6 \mathrm{~g})$ and $\mathrm{MeOH}(3 \times 1000 \mathrm{~mL} .25 \mathrm{~g})$ at room temperature with constant stirring for $24 \mathrm{~h}$ for each solvent. The $\mathrm{MeOH}$ extract $(20 \mathrm{~g}$ ) was fractionated by flash colunu chromatography ( $\$$ i gel $60.0 .015 \sim 0.040 \mathrm{~mm}$. Merck) by using a gadient of increasing polarity with $\mathrm{CH}_{2} \mathrm{Cl}_{2}$, EtOAc, and $\mathrm{MeOH}$ as the solvent. to yield 21 fractions ( $500 \mathrm{~mL}$ each). Fractions 14. 15,16 . and 17 were selected by the moderate inhibition effect of $\mathbb{L}-6$ in the HMC- 1 line and combined for further separation. This mixture was concentrated to a brown viscous residue under reduced pressure at less than $40^{\circ} \mathrm{C}$. and then dissolved in $\mathrm{H}_{2} \mathrm{O}(250 \mathrm{~mL})$ and partitioned with water-saturated $n-\mathrm{BuOH}$. After solvent removal, the residue of the $n-\mathrm{BuOH}$ fraction $(8.1 \mathrm{~g}$ ) was dissolved in a small amount of $\mathrm{MeOH}(50 \mathrm{~mL})$ and purified by precipitation with $\mathrm{Et}_{2} \mathrm{O}(2 \times 250 \mathrm{~mL})$. yielding a cnude saponin nixture (7.12 g). This mixture was subjected to a reversedphase flash column chromatography (YMC Gel ODS-A $12 \mathrm{~nm}$ S-75 $\mu \mathrm{m}$ ) using step mixtures of the $\mathrm{H}_{2} \mathrm{O} / \mathrm{MeOH}$ solvent system $(100 / 0,30 / 70$. and $0 / 100)$. The $70 \% \mathrm{MeOH}(2.1$ g) subfraction was further purified by reversed-phase senupreparative HPLC eluting with a $65 \%$ aqueous $\mathrm{MeOH}$ solvent in a flow rate of 2 $\mathrm{mL} / \mathrm{min}$ to afford sativoside $\mathrm{A}\left(1,14 \mathrm{mg}, t_{\mathrm{R}}=18 \mathrm{~min}\right)$. sativoside $\mathrm{B}\left(2.13 \mathrm{mg}, t_{\mathrm{R}}=33.1 \mathrm{~min}\right) .3\left(600 \mathrm{mg}, t_{\mathrm{R}}=21.9 \mathrm{~min}\right) .+(60 \mathrm{mg}$. $\left.t_{\mathrm{R}}=24.4 \mathrm{~min}\right) .5\left(15 \mathrm{mg} t_{\mathrm{R}}=28.3 \mathrm{~min}\right)$. and $6\left(6 \mathrm{mg}, t_{\mathrm{R}}=31.2 \mathrm{~min}\right)$.

Sativoside A (1) : [a] ${ }_{\mathrm{D}}^{2}+24.6^{\circ}$ (co.1. MeOH); IR (film) 3389 $(\mathrm{OH}) .293 \mathrm{l}(\mathrm{CH}), 1728(\mathrm{C}=\mathrm{O}), 1644(\mathrm{C}=\mathrm{C}), 1027-1039(\mathrm{C}-\mathrm{O})$ $\mathrm{cm}^{-1}:{ }^{1} \mathrm{H}$ and ${ }^{13} \mathrm{C}$ NMR are given in Tables $\mathrm{I}$ and 2 : HRFABMS $m z: 1375.6517$ (calcd for $\mathrm{C}_{64} \mathrm{H}_{144} \mathrm{O}_{31} \mathrm{Na}: 1375.6510$ ).

Sativoside B (2) : [a] $]_{\mathrm{D}}+7.2^{\circ}(c 0.1, \mathrm{MeOH})$ : IR (film) 3366 $(\mathrm{OH}) .2929(\mathrm{CH}) .1717(\mathrm{C}=\mathrm{O}), 1624(\mathrm{C}=\mathrm{C}), 1027-1039(\mathrm{C}-\mathrm{O})$ $\mathrm{cm}^{-1}:{ }^{1} \mathrm{H}$ and ${ }^{13} \mathrm{C}$ NMR are given in Tables $\mathrm{l}$ and 2: HRFABMS $m z: 1373.6346$ for $[\mathrm{M}+\mathrm{Na}]^{+}$(Calcd for $\left.\mathrm{C}_{64} \mathrm{H}_{102} \mathrm{O}_{301} \mathrm{Na}: 1373.6354\right)$.

Sugar analysis. Each compound (each $5.0 \mathrm{ng})$ in $\mathrm{H}_{2} \mathrm{O}(2 \mathrm{~mL})$ and $2 \mathrm{~N} \mathrm{CF}_{3} \mathrm{COOH}(5 \mathrm{~mL})$ were refluxed on a water bath at 75 ${ }^{\circ} \mathrm{C}$ for $6 \mathrm{~h}$. Then, the reaction mixture was diluted with $\mathrm{H}_{2} \mathrm{O}$ $(10 \mathrm{~mL})$ and extracted with EtOAc $(3 \times 20 \mathrm{~mL})$. The combined EtOAc extracts were washed with $\mathrm{H}_{2} \mathrm{O}$ and evaporated to dryness to afford the aglycon. The aqueous layer was repeatedly evaporated to dryness with $\mathrm{MeOH}$ and the residue was dissolved in $\mathrm{CH}_{3} \mathrm{CN}-\mathrm{H}_{2} \mathrm{O}$ (1:1) followed by $\mathrm{HPLC}$ analysis, using an isocratic elution of $\mathrm{CH}_{3} \mathrm{CN}-\mathrm{H}_{2} \mathrm{O}(85: 15)$ with $\mathrm{RI}$ detection in a flow rate of $0.9 \mathrm{~mL} /$ min Coelution experiments with standard sugar sanples allowed the identification of rhamnose $\left(t_{\mathrm{R}}=7.13 \mathrm{~min}\right)$. sylose $\left(t_{\mathrm{R}}=\right.$ 8.06 nin). arabinose ( $\left.t_{\mathrm{R}}=8.86 \mathrm{nuin}\right)$, and glucose $\left(t_{\mathrm{R}}=11.35 \mathrm{nuin}\right)$. Co-injection of each hydrolysate with standard L-rhanmose. D-xylose. L-arabinose, and D-glucose yielded consistent peaks. 
And then each of these elutes were individually collected, evaporated to dryness and dissolved in $\mathrm{H}_{2} \mathrm{O}$ and the optical rotation was then recorded at room temperature.

Cell culture. The HMC-1 cells were grown in IMDM and supplemented with $100 \mathrm{U} / \mathrm{mL}$ penicillin. $100 \mu \mathrm{g} / \mathrm{mL}$ streptony cin.

Table 2. NMR Spectral Data of the Sugar Portion of sativosides A (1) and $\mathrm{B}(2)$ in $\mathrm{CD}_{3} \mathrm{OD}$

\begin{tabular}{|c|c|c|c|c|}
\hline \multirow{2}{*}{ no } & \multicolumn{2}{|l|}{1} & \multicolumn{2}{|l|}{2} \\
\hline & $\delta_{\mathrm{H}}$ & $\delta$ & $\delta_{H}$ & $\delta$ \\
\hline \multicolumn{5}{|c|}{$\mathrm{C}-3$} \\
\hline \multicolumn{5}{|c|}{ Ara } \\
\hline 1 & $4.50(1 \mathrm{H}, \mathrm{d}, 5.4)$ & $104.7, d$ & $4.22(1 \mathrm{H}, \mathrm{d}, 3.5)$ & $103.0, d$ \\
\hline 2 & $3.69^{a}$ & $76.0, d$ & $3.63^{\circ}$ & $75.3, d$ \\
\hline 3 & $3.68^{a}$ & $74.2, d$ & $3.62^{a}$ & $74.4, d$ \\
\hline 4 & $3.75(1 \mathrm{H}, \mathrm{bs})$ & $69.7, d$ & $3.70^{\circ}$ & $69.6, d$ \\
\hline $5 a$ & $3.51^{4 i}$ & $65.5, t$ & $3.45(1 \mathrm{H}, \mathrm{bs})$ & $65.7, t$ \\
\hline $5 b$ & $3.84(1 \mathrm{H}, \mathrm{d}, 3.7)$ & & $3.80(1 \mathrm{H}, \mathrm{d}, 3.6)$ & \\
\hline \multicolumn{5}{|c|}{ Rha I } \\
\hline 1 & $5.23(\mathrm{lH}, \mathrm{bd}, 1.2)$ & $101.2, d$ & $5.20(1 \mathrm{H}, \mathrm{bd}, 1.5)$ & $100.9, d$ \\
\hline 2 & $4.07^{\prime \prime}$ & $71.6, d$ & $4.00(1 \mathrm{H}, \mathrm{t}, 1.5)$ & $71.9, d$ \\
\hline 3 & $3.83^{4}$ & $82.1, d$ & $3.87^{a}$ & $81.9, d$ \\
\hline 4 & $3.56(1 \mathrm{H}, \mathrm{bd}, 3.9)$ & $72.7, d$ & $3.53(\mathrm{IH}, \mathrm{dd}, 3.9,3.9)$ & $72.9, d$ \\
\hline 5 & $3.92(1 \mathrm{H}, \mathrm{d}, 3.4)$ & $69.9, d$ & $3.87^{a}$ & $69.6, d$ \\
\hline 6 & $1.24(3 \mathrm{H}, \mathrm{d}, 6.1)$ & $17.8, q$ & $1.25(3 \mathrm{H}, \mathrm{d}, 6.1)$ & $17.8,9$ \\
\hline \multicolumn{5}{|c|}{$\mathrm{Xyl}$} \\
\hline 1 & $4.47(1 \mathrm{H}, \mathrm{d}, 7.3)$ & $106.5, d$ & $4.58(1 \mathrm{H}, \mathrm{d}, 7.1)$ & $106.6, d$ \\
\hline 2 & $3.29^{a}$ & $75.2, d$ & $3.28^{a}$ & $75.3, d$ \\
\hline 3 & $3.41^{a}$ & $78.3, d$ & $3.38^{a}$ & $78.2, d$ \\
\hline 4 & $3.49(1 \mathrm{H}, \mathrm{m})$ & $71.0, d$ & $3.47^{a}$ & $71.1, d$ \\
\hline $5 a$ & $3.21^{4}$ & $66.9, t$ & $3.24^{4}$ & $67.0, t$ \\
\hline $5 b$ & $3.87(1 \mathrm{H}, \mathrm{d}, 5.3)$ & & $3.85(1 \mathrm{H}, \mathrm{d}, 5.3)$ & \\
\hline \multicolumn{5}{|c|}{ C-28 } \\
\hline \multicolumn{5}{|c|}{ Glc I } \\
\hline 1 & $5.46(1 \mathrm{H}, \mathrm{d}, 8.3)$ & $95.7, d$ & $5.32(1 \mathrm{H}, \mathrm{d}, 8.1)$ & $95.8, d$ \\
\hline 2 & $3.30^{4}$ & $76.7, d$ & $3.31^{a}$ & $75.3, d$ \\
\hline 3 & $3.54^{4}$ & $78.0, d$ & $3.51(1 \mathrm{H}, \mathrm{d}, 3.4)$ & $78.1, d$ \\
\hline 4 & $3.46(1 \mathrm{H}, \mathrm{dd}, 2.7,2.7)$ & $70.8, d$ & $3.38(1 \mathrm{H}, \mathrm{dd}, 2.7)$ & $70.9, d$ \\
\hline 5 & $3.32^{a}$ & $77.5, d$ & $3.32(\mathrm{IH}, \mathrm{bs})$ & $77.7, d$ \\
\hline $6 a$ & $3.81^{a}$ & $69.7,1$ & $3.78^{a}$ & $69.4, t$ \\
\hline $6 b$ & $4.07(1 \mathrm{H}, \mathrm{d}, 11.5)$ & & $4.07(1 \mathrm{H}, \mathrm{d}, 11.5)$ & \\
\hline \multicolumn{5}{|c|}{ Gle II } \\
\hline 1 & $4.35(1 \mathrm{H}, \mathrm{d}, 7.8)$ & $104.7, d$ & $4.39(1 \mathrm{H}, \mathrm{d}, 8.1)$ & $1042, d$ \\
\hline 2 & $3.23^{a}$ & $75.2, d$ & $3.22(1 \mathrm{H}, \mathrm{bs})$ & $75.3, d$ \\
\hline 3 & $3.29^{a}$ & $76.7, d$ & $3.27^{a}$ & $76.8, d$ \\
\hline 4 & $3.53^{4}$ & $79.5, d$ & $3.51(1 \mathrm{H}, \mathrm{d}, 3.4)$ & $79.5, d$ \\
\hline 5 & $3.46^{6 \prime}$ & $76.6, d$ & $3.45(1 \mathrm{H}, \mathrm{bs})$ & $76.7, d$ \\
\hline $6 a$ & $3.65(1 \mathrm{H}, \mathrm{d}, 4.2)$ & $61.8, t$ & $3.63^{a}$ & $61.8, t$ \\
\hline $6 b$ & $3.79^{\circ}$ & & $3.78^{a}$ & \\
\hline \multicolumn{5}{|c|}{ Rha II } \\
\hline 1 & $4.84(1 \mathrm{H}, \mathrm{bs})$ & $102.8, d$ & $4.82(1 \mathrm{H}, \mathrm{bs})$ & $102.9, d$ \\
\hline 2 & $3.83^{4}$ & $72 . \hat{3}, d$ & $3.82(1 \mathrm{H}, \mathrm{d}, 2.7)$ & $72.4, d$ \\
\hline 3 & $3.63(1 \mathrm{H}, \mathrm{t}, 3.5)$ & $72.1, d$ & $3.61(1 \mathrm{H}, \mathrm{d}, 3.2)$ & $72 . \hat{3}, d$ \\
\hline 4 & $3.40^{\circ}$ & $73.6, d$ & $3.39^{\circ}$ & $73.9, d$ \\
\hline 5 & $3.95(1 \mathrm{H}, \mathrm{d}, 3.4)$ & $70.6, d$ & $3.96(1 \mathrm{H}, \mathrm{d}, 3.4)$ & $70.6, d$ \\
\hline 6 & $1.26(3 \mathrm{H}, \mathrm{d}, 6.3)$ & $17.7, q$ & $1.26(3 \mathrm{H}, \mathrm{d}, 6.3)$ & $17.8, q$ \\
\hline
\end{tabular}

"Overlaped with other signals. $q=\mathrm{CH}_{3}, t=\mathrm{CH}_{\hat{\imath}}, d=\mathrm{CH}$. and $10 \%$ fetal bovine serum (FBS) at $37^{\circ} \mathrm{C}$ in $5 \% \mathrm{CO}_{2}$ with $95 \%$ humidity. The HMC-l cells were treated with new triterpene saponin compounds for $1 \mathrm{~h}$. The cells were then stimulated with $50 \mathrm{nM}$ of phorbol 12-myristate 13-acetate (PMA) plus 1 $\mu \mathrm{M}$ of $\mathrm{A} 23187$ and incubated at $37{ }^{\circ} \mathrm{C}$ for $8 \mathrm{~h}$.

MTT assay for cell viability. Cell viability was examined by an MTT assay. After HMC-I aliquots were seeded $\left(3 \times 10^{5}\right)$ in microplate wells. The conpounds $(5,10,50$. and $100 \mu \mathrm{g} / \mathrm{mL}$ ) were added to each well and incubated with $10 \mu \mathrm{L}$ of an MTT solution $\left(5 \mathrm{mg} / \mathrm{mL}\right.$ ) for 4 h at $37^{\circ} \mathrm{C}$ under $5 \% \mathrm{CO}_{2}$ and $95 \%$ air. Then. the supernatant was removed and the formazone crystals were dissolved by the addition of $100 \mu \mathrm{L}$ of DMSO. An automatic microplate reader was used to read the absorbance of each well at $590 \mathrm{~nm}$

Cytokine assay. The $\mathrm{HMC}-\mathrm{I}$ cells were pretreated with two concentrations of six compounds ( 5 and $10 \mu \mathrm{g} / \mathrm{mL}$ ) for 1 h before PMA plus A23187-stimulation. We then used the enzymelinked immulosorbent assay (ELISA) nethod to assay the culture supernatants for the IL -6 protein levels. To measure the cytokine IL-6. we used a modified ELISA method. We first conducted a sandwich ELISA for $\mathbb{L}-6$ in duplicate in 96 -well ELISA plates (Nunc. Denmark). Then, the supernatant was decanted into a new microcentrifuge tube and the cy tokine was quantitated by ELISA ELISA plates (Falcon. Becton Dickinson Labware. Franklin Lakes, NJ) were coated overnight at $4^{\circ} \mathrm{C}$ with anti-human IL- 6 monoclonal antibody diluted in coating buffer $(0.1 \mathrm{M}$ carbonate. $\mathrm{pH} 9.5$ ) and then washed four times with phosphate buffered saline (PBS) containing $0.05 \%$ Tween 20 . The nonspecific protein binding sites were blocked with assay diluent (PBS containing $10 \% \mathrm{FBS}, \mathrm{pH} 7.0$ ) for at least $1 \mathrm{~h}$. After washing the plates again the test sample or recombinant $\amalg-6$ standards were added. After incubation for $2 \mathrm{~h}$ a working detector (biotinylated anti-human $\mathbb{L}-6$ monoclonal antibodies and streptavidin-horseradish peroxidase reagent) was added and incubated for $\mathrm{l} h$. Accordingly. substrate solution (tetramethylbenzidine) was added to the wells and incubated for $30 \mathrm{~min}$ in the dark before the reaction was stopped with a solution of $2 \mathrm{~N} \mathrm{H}_{3} \mathrm{PO}_{4}$. The absorbance was recorded at $450 \mathrm{~nm}$. All subsequent steps took place at room temperature. and all standards and samples were assayed in duplicate.

Statistical analysis. Statistical analy'sis was performed using one-way analysis of variance (ANOVA) followed by Dumnett's t-test for multiple comparisons. and Student 's test for single comparisons. The data from the experiments are presented as means \pm S.E.M.

\section{Results and Discussion}

The $n$-butanol fractions obtained from the methanolic extract of the seeds of $\mathrm{X}$. sativa were suspended in $\mathrm{MeOH}$ and purified by precipitation with $\mathrm{Et}_{2} \mathrm{O}$ yielding a crude saponin mixture. This extract was further fractionated by a combination of silica gel and RP-18 flash column chromatography. followed by semipreparative reversed-phase HPLC to afford two new saponins, sativosides A (1) and B (2), together with four known compounds (Figure 1).

Sativoside A (1) was isolated as a white amorphous powder and its molecular formula was established as $\mathrm{C}_{644} \mathrm{H}_{104} \mathrm{O}_{311}$ on the 


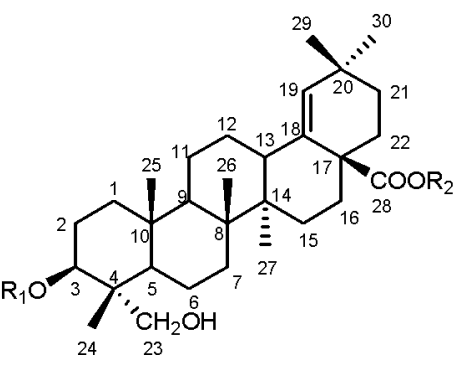

I

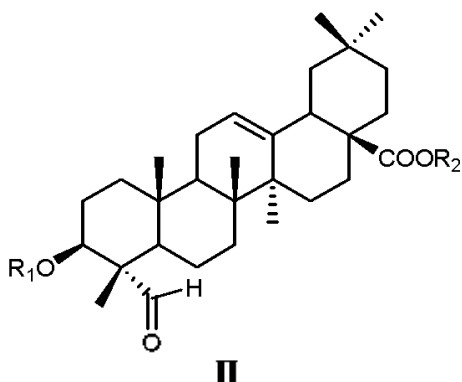

II

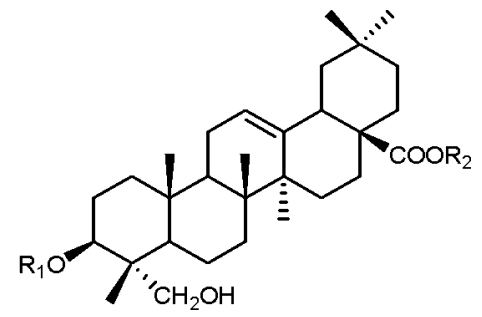

III

\begin{tabular}{|c|c|c|}
\hline compounds & aglycon & $\mathrm{R}_{1}$ \\
\hline 1 & I & $\beta-D-X v 1(1 \rightarrow 3)-\alpha-L-R h a I(1 \rightarrow 2)-\alpha-L-A r a$ \\
\hline 2 & II & $\beta-\mathrm{D}-\mathrm{XVl}(1 \rightarrow 3)-\alpha-\mathrm{L}-\mathrm{Rha} \mathrm{I}(1 \rightarrow 2)-\alpha-\mathrm{L}-\mathrm{Ara}$ \\
\hline 3 & III & $\beta-D-X v l(1 \rightarrow 3)-\alpha-L-R h a I(1 \rightarrow 2)$ - $\alpha$-L-Ara \\
\hline 4 & III & $\alpha-L-R i h a I(1 \rightarrow 2)-\alpha x-L-A T a$ \\
\hline 5 & III & $\beta$-D-Xy1 $(1 \rightarrow 3)-\alpha-L-R h a(1 \rightarrow 2)-\alpha-L-A r a$ \\
\hline 6 & III & $\alpha-L-$ Rha $(1 \rightarrow 2)-\alpha-L-A r a$ \\
\hline
\end{tabular}

$\mathrm{R}_{2}$

$\alpha$-L-Rha II $(1 \rightarrow 4)$ - $\beta$-D-Glu II $(1 \rightarrow 6)-\beta$-D-Gilu I $\alpha$-L-Rha II $(1 \rightarrow 4)-\beta$-D-Glu II ( $1 \rightarrow 6$ )- $\beta$-D-Glu I $\alpha$-L-Rha II $(1 \rightarrow 4)$ - $\beta$-D-Glu II $(1 \rightarrow 6$ - $\beta$-D-Glu I $\alpha$-L-Rha II $(1 \rightarrow 4)-\beta$-D-Glu II $(1 \rightarrow 6)-\beta$-D-Glu I $\beta$-D-Gilu II $(1 \rightarrow 6)$ - $\beta$-D-Glu I $\beta$-D-Glu II $(1 \rightarrow 6)$ - $\beta$-D-Glu I

Figure 1. Structures of Saponins 1-6 isolated from Nigella sativa $\mathrm{L}$.

basis of a combination of a peak at $m: z 1375.6517[\mathrm{M}-\mathrm{Na}]^{-}$ (calcd 1375.6510) of HRFABMS and the ${ }^{13} \mathrm{C}$ NMR spectrum. The IR spectrum showed strong absorption bands at 3389 and $1728 \mathrm{~cm}^{-1}$, typical of the hydroxyl and carbonyl group. respectively. The ID NMR spectra $\left({ }^{\mathrm{H}} \mathrm{H} .{ }^{13} \mathrm{C}\right.$ and DEPT) of $\mathbf{1}$ displayyed the presence of eight methyls. one double bond and one carboxylic group. All signals observed in the upfield $(0.5 \sim 2.5$ ppm) and midfield $(3.0 \sim 5.5 \mathrm{ppm})$ region of the ${ }^{\mathrm{l}} \mathrm{H} \mathrm{NMR}$ spectrum deduced compound 1 to be a triterpene glycoside. together with anomeric signals corresponding to six monosaccharide residues in the HSQC spectrum. From careful analy sis with 1D and 2D NMR data (COSY. TOCSY. HSQC and $\mathrm{HMBC}$ ), the aglycon part of 1 was revealed to be a triterpene of 3,23-dihydroxyolean-18-en-28-oic acid claracteristic of six methyl singlets at $\delta 0.68,0.81,0.93,0.97,0.99$. and 1.01. two diastereotopic protons at $\delta 3.33$ and 3.51 ascribable to a $\mathrm{CH}_{2} \mathrm{OH}$ group and a broad singlet at $\delta 5.14$. The position of the double bond at $\Delta^{18: 191}$ was evident from the HMBC correlations of two methyl protons at $\delta 0.97$ and 0.99 with the olefinic carbon at $\delta 13+.0(C-19)$ and of the proton at $\delta 5.14$ with two carbons at $\delta 42.3(\mathrm{C}-13)$ and $49.9(\mathrm{C}-17)$. The linkage of the $\mathrm{CH}_{2} \mathrm{OH}$ and the carbonyl carbon groups to two quaternary carbons at $\mathrm{C}-4$ and $\mathrm{C}-17$, respectively. was also secured by the $\mathrm{HMBC}$ comelations between two methylene protons at $\delta 3.33$ and $3.5 \mathrm{I}$ and the carbon at $\vec{\delta} 44.1(\mathrm{C}-4)$ and between the proton at o $2.02(\mathrm{H}-16)$ and the carbonyl carbon at ò $177.0(\mathrm{C}-28)$. The relative stereochemistry of all chiral centers in the aglycon part of 1 was achieved by the ROESY experiment. The configuration of the glycosylated $\mathrm{OH}$ group at $\mathrm{C}-3$ was assigned to be $\beta$ from the NOE peak between $\mathrm{H}-3$ and $\mathrm{H}-5$. And the NOE effect between $\mathrm{H}_{3}-2+$ and $\mathrm{H}_{3}-25$ indicated that the methyl group at $\mathrm{C}-2+$ was in a $\beta$ position. The carbonyl group at $\mathrm{C}-28$ was established to be oriented in the $\beta$-axial direction based on the observation of the NOE peak between $\mathrm{H}-16 \mathrm{~b}$ and $\mathrm{H}-22 \mathrm{~b}$. $^{2+35}$

The monosaccharide residues in the glycosidic part of 1 were assigned by a combination of COSY. TOCSY and HSQC spectra. starting from the well-separated anomeric protons at $\delta 4.35$ (d. $J=7.8 \mathrm{~Hz}$ ). 4.47 (d. $J=7.3 \mathrm{~Hz}), 4.50(\mathrm{~d} . J=5.4 \mathrm{~Hz}), 4.84(\mathrm{bs})$,
5.23 (bd. 1.2) and 5.46 (d. $J=8.3 \mathrm{~Hz}$ ). Based on the evaluation of spin-spin couplings and ROESY data. the existence of two $\beta$-glucopyranosyl (Glc), one $\beta$-xylopy ranoșyl (Xyl). one $\alpha$-arabinopyranosyl (Ara), and two $\alpha$-rhannopy ranosyl (Rha) residues were recognized. This is confirmed by both HPLC analysis with authentic sugars after acid hydrolysis of $\mathbf{1}$ and optical rotation measurement for each isolated residue. indicating that the sugar part was composed of rhamnose (L-Rha). xylose (D-Xyl). arabinose (L-Ara). and glucose (D-Glu) in a ratio of $2: 1: 1: 2$. Then, the sequence of monosaccharide units in the glycosidic part was established from the HMBC and ROESY spectra. In the HMBC experiment (Figure 2), the downfield shifted carbon at $\mathrm{C}-3$ of the aglycon showed long-range correlation with the proton at $\hat{o}+.50(\mathrm{H}-1)$ of the Ara residue, of which C-2 was in turn connected to the $\mathrm{H}-\mathrm{l}$ of Rha I via an ether linkage from the correlations between the anomeric proton at $\delta 5.23(\mathrm{H}-1)$ of Rha I and C-2 $(\delta 76.0)$ of Ara unit. An additional HMBC correlation between the $\mathrm{H}-\mathrm{L}(\delta 4.47)$ of Xyl and C-3 $(\delta 82.1)$ of Rha I completed the linkage of the trisaccharide chain at $\mathrm{C} 3$ of the aglycon part. Followed by the same analysis. the 28-O-triglycoside structure of 1 was characterized on the basis of the HMBC cross-peaks between $\mathrm{H}-1(\delta 5.46)$ of Glc I and $\mathrm{C}-28(\delta 177.0)$ of the aglycon part. $\mathrm{H}-1(\delta 4.35)$ of Glc II

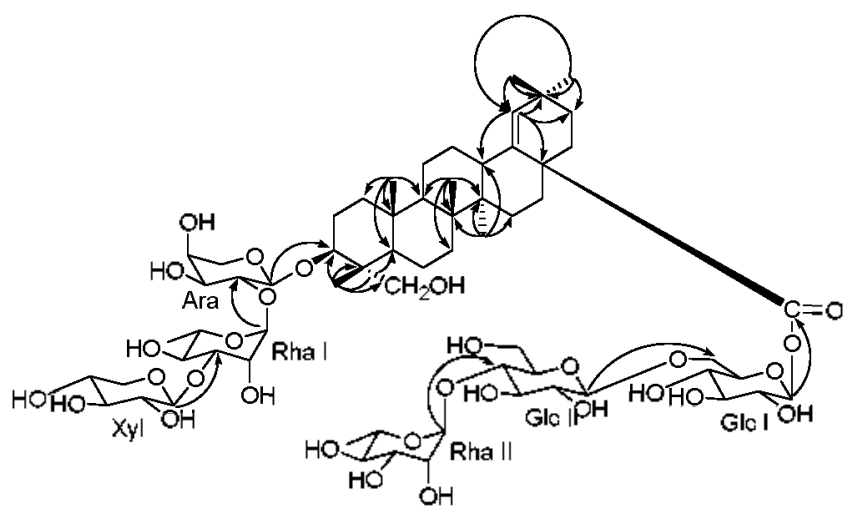

Figure 2. key HMBC correlations for Sativoside A (1). 
Table 3. Effect of compounds 1-6 on IL-6 production

\begin{tabular}{|c|c|c|c|c|}
\hline \multirow{2}{*}{\multicolumn{2}{|c|}{ control }} & IL-6 (pg/mLL) & \multirow{3}{*}{$\begin{array}{l}\text { Inhibition } \\
\text { rate (\%) }\end{array}$} & \multirow{3}{*}{$\mathrm{IC}_{\mathrm{s}_{0}}(\mu \mathrm{g} / \mathrm{mL})$} \\
\hline & & $3 \pm 1$ & & \\
\hline & $+\mathrm{A} 23187$ & $679 \pm 4$ & & \\
\hline \multirow{2}{*}{1} & $10 \mu \mathrm{g} / \mathrm{mL}$ & $386 \pm 8$ & 43 & 12.6 \\
\hline & $5 \mu \mathrm{g} / 112 \mathrm{~L}$ & $572 \pm 22$ & 16 & \\
\hline \multirow{2}{*}{2} & $10 \mu \mathrm{g} / \mathrm{mL}$ & $265 \pm 21$ & 61 & 8.5 \\
\hline & $5 \mu \mathrm{g} / \mathrm{mL}$ & $510 \pm 7$ & 25 & \\
\hline \multirow{2}{*}{3} & $10 \mu \mathrm{g} / \mathrm{mLL}$ & $271 \pm 18$ & 60 & 7.6 \\
\hline & $5 \mu \mathrm{g} / \mathrm{mL}$ & $422 \pm 25$ & 38 & \\
\hline \multirow{2}{*}{4} & $10 \mathrm{\mu g} / \mathrm{mLL}$ & $549 \pm 15$ & 19 & 30.9 \\
\hline & $54 \mathrm{~g} / 112 \mathrm{~L}$ & $695 \pm 24$ & 0 & \\
\hline \multirow{2}{*}{5} & $10 \mu \mathrm{g} / \mathrm{mL}$ & $678 \pm 11$ & 0 & - \\
\hline & $5 \mu \mathrm{g} / \mathrm{mL}$ & $675 \pm 6$ & 0 & \\
\hline \multirow{2}{*}{6} & $10 \mu \mathrm{g} / \mathrm{mL}$ & $533 \pm 10$ & 22 & 23.4 \\
\hline & $5 \mu \mathrm{g} / \mathrm{mL}$ & $674 \pm 3$ & 0 & \\
\hline
\end{tabular}

and $\mathrm{C}-6(\delta 69.7)$ of Glc. H-4 ( $\delta 3.53)$ of Glc II and C-1 $(\delta \mathrm{I} 102.8)$ of Rha II, and H-1 $(\delta+.84)$ Rha II and C-4 $(\delta 79.5)$ of Gle II. The unequivocal sequence of two trisaccharide chains was also supported from ROESY peaks between the anomeric protons and the proton in the adjacent residue. The triterpene glycoside isolated from Oreopanax guatemalensis is the closest relative. ${ }^{35}$ Thus. the structure of 1 was determined as 3-O-[ $\beta$-D-xylopyranosy l-( $1 \rightarrow 3)-O$-[ $\alpha$-L-rhamnopy ranosyl$(1 \rightarrow 2)$ - $O-\alpha$-L-arabinopy ranosyl] $3 \beta .23$-dihydroxy olean-18en-28-oic acid $28-O$-[ $\alpha$-L-rhamnopy ranoș $\mathrm{l}-(1 \rightarrow 4)-O-\beta \mathrm{D}$-glucopy ranosyl- $(1 \rightarrow 6)-\beta$-D-glucopy ranosyl] ester. To the best of our knowledge. compared with common bisdesmosidic saponins with trisaccharide chains at $\mathrm{C}-3$ and $\mathrm{C}-28$ of the aglycon the aglycon of 1 possesses a rare olean-18-en moiety. This is the first reported occurrence of an olean-18-en type saponin in fanily Ranunculacea.

Sativoside B (2) exhibited a quasimolecular ion peak at $m: z$ $1373.63+6[\mathrm{M}+\mathrm{Na}]^{+}$(calcd 1373.6354) consistent with the molecular formula $\mathrm{C}_{64} \mathrm{H}_{1} \mathrm{O}_{3}$ in the HRFABMS. As described previously the signal assignment of $\mathbf{2}$ from extensive ID and 2D NMR spectroscopic studies suggested a bisdesmosidic saponin with two trisaccharides at the $\mathrm{C}-3$ and $\mathrm{C}-28$ position of the aglycon with the olean-12-en type. gypsogenin. ${ }^{-6}$ And the acid hydrolysis followed by HPLC analysis and optical activity measurement revealed sugar components to be the same with those of 1 . The feature of 2 indicated the presence of an aldehydic group. confirmed by the signal at 0.50 in the ${ }^{1} \mathrm{H} N \mathrm{NR}$ spectrum and by the signal at $\delta 209.3$ in the ${ }^{13} \mathrm{C}$ NMR spectnum. This group was connected to the position of $\mathrm{C}-4$ from the HMBC correlation from the downfield shifted aldehydic proton at o 9.50 to the quatemary carbon at $\delta 56.3(\mathrm{C}-4)$. Accordingly compound 2 was identified as a $3-O-[\beta$-D-xylopyranosyl- $(1 \rightarrow 3)-O-[\alpha-L-r h a m n o p y r a n o s y l-(1 \rightarrow 2)-0-\alpha-L-$ arabinopyranosyl] gy psogenin 28-O-[ $\alpha$-L-rhamnopy ranosyl$(1 \rightarrow 4)-O-\beta$-D-glucopyranosy l-( $1 \rightarrow 6)-\beta$-D-glucopyranosyl] ester. The survey showed that the elucidated structure of 2 was very similar to that of 3 reported recently from the seeds of $N$. sativa. ${ }^{1+}$ Compound 2 may be inferred to be oxidized from 3 in the biosy nthesis pathway.

Compounds 4-6 were determined as the known triterpene glycosides by analysis of the 2D NMR data by the same procedure as 1 : 4 was suggested to be a 3-O-[ $\alpha$-L-rhanmopy ranosy $1-(1 \rightarrow 2)$ $O$ - $\alpha$-L-arabinopy ranosyyl] hedragenin 28-O-[a-L-rhamnopyranosyl- $(1 \rightarrow 4)$ - $O-\beta$-D-glucopyranosyl- $(1 \rightarrow 6)-\beta$-D-glucopyranoșyl] ester $5^{14}$ a $3-O-[\beta-\mathrm{D}$-xylopyranosyl- $(\mathrm{l} \rightarrow 3)-O-[\alpha-\mathrm{L}-$ rhanuopyranosyl-(1 $\rightarrow 2)-O-\alpha$-L-arabinopy ranosyl] hedragenin 28 - $O$-[ $\beta$-D-glucopy ranosyl-( $1 \rightarrow 6)-\beta$-D-glucopyranosy 1$]$ ester, previously reported from Cephalaria pastricensis and 6 as a $3-O$-[ $\alpha$-L-rhamnopy ranosyl- $(1 \rightarrow 2)-O$ - $\alpha$-L-arabinopyranosyl] hedragenin $28-O$ - $[\beta$-D-glucopyranosyl-( $1 \rightarrow 6)-\beta$-D-glucopyranosyl] ester. isolated from $C$ pasticensis and $N$ glandulifer $a$ Freyn. $^{28}$ However, the latter saponins 5 and 6 were not previously reported from the Nigella genus

We examined the inhibition effect of the six isolated compounds on PMA plus calcium ionophore A23187-induced production of pro-inflanmatory cy tokine IL- 6 in the HMC-1 line. which may be important in developing future anti-inflammatory therapies. Although weak cy totoxicity at high concentration of $100 \mu \mathrm{g} / \mathrm{mL}$, all compounds were found not to affect HMC-1 cells viability at concentrations of $5,10,50$ and $100 \mu \mathrm{g} / \mathrm{mL}$ (data not shown). As shown in Table 3. the levels of IL-6 was considerably increased after stimulation with PMA plus A23 187 in HMC-1. Treatment of cell with compounds 1-3 (5 and $10 \mu \mathrm{g}$ $\mathrm{mL}$ ) significantly inhibited $\amalg-6$ production in a concentrationdependent and statistically significant manner.

Acknowledgments. This research was financially supported by the Brain Korea 21 (BK21) project, Ministry of Education \& Human Resources Development. Republic of Korea.

\section{References}

1. Nadkami, A. K. Indion Materia ledica; Popular Prahashan Pvt. Ltd, Bombay, 1976; pp 301-340

2. Jansen, P. C. M. Spices, Condiments and Medicinal Plants in Ethopia, thei Taxonomy and Agicultwal Significance, Center for Agiculmal Publishing and Documentation: Addis Ababa. $1981 ;$ pp $76-85$.

3. Aboutabl, E. R; El-Azzouy, A. A.; Hammerschmidt, F. I. Prog. Essent. Oil Res. 1986, 16, 49

4. Merfort, I.: Wary, V.: Barakat. H. H.: Hussein. S. A. M.: Nawwar, M. A. M.; Willuhn, G. Phytochemistny 1997, 46, 359.

5. Ramadan, M. F. Inter. J. Food Sci. Technol. 2007, 42, 1208.

6. Mahmood, M. S.; Gilani, A. H.; Khwaja, A.; Rashid, A.; Ashfaq, M. K. Phytother: Res. 2003, 17, 921

7. Hanafy M. S. M.; Hatem, M. E. J. Ethophomacol. 1991, 34, 275.

8. Schleicher, P.; Saleh, M. Black Seed Cumin: the Magical Eguptian Herb for Allergies, Asthma, and Immme Disorders; Healing Arts Press; Rochester, Vermont, 1998.

9. Ali, B. H.; Blunden, G. Phvtother Res. 2003, 17, 299.

10. Salem, M. L. Inter Inmmophamacol. 2005, $5,1749$.

11. Morikawa, T.; Xu, F.: Kashima, Y.; Matsuda, H.; Ninomiya, K.; Yoshikawa, M. Org. Lett. 2004, 6, 869.

12. Morikawa, T.; Xu, F.: Ninomiya, K.: Matsuda, H.; Yoshikawa, M. Chem. Pham. Bull. 2004, $4,494$.

13. Swamy, S. M. K: Benny, T. K. H. Planta led. 2001, 67, 29.

14. Taskin, M. K. Caliskan, O. A.: Anil, H.; Aboll-Gazar, H.; Khan, I. A.: Bedir, E. Tuw. J. Chem. 2005, 29, 561.

15. Lacaille-Dubois, M. A.; Wagner. H. Bioactive Saponins from Plonts: An Lipdate. In studies in Katural Products Chemistry 
Series; Atta-Ur6Rahman., ED; Elsevier Science: Amesterdan, Netherlands, 2000; Vol. 21, pp 633-687.

16. Shi, T; Arunasalam, K: Yeung, D:; Kaknda, Y:; Mittal, G.: Tiang, Y. J. Afed. Food 2004, 7,67.

17. Guclu-Ustundag, O; Mazza, G. Crft. Rev. Food Sci. Nutr. 2007, $47,2.31$

18. Elbandy, M: Miyanoto, T.: Lacaille-Dubois, M. A. Helv. Chim. Acta 2007,90,260.

19. Elbandy, M.; Miyamoto, T.: Delaude, C.: Lacaille-Dubois, M. A. Helv. Chim .icta $2004,87,340$.

20. Elbandy, M.: Miyamoto, T.; Delaude, C.: Lacaille-Dubois, M. A. J. Sat. Prod. 2003, 66, 1154.

21. Elbandy, M.; Miyamoto, T.; Delaude, C: Lacaille-Dubois, M. A. Helv. Chim . icta $2003,86,522$.
22. Elbandy, M.: Miyamoto, T.: Delande, C.: Lacaille-Dubois, M. A. Helv. Chim . Acta 2002, 85, 2721 .

23. Elbandy, M.: Mivamoto, T.; Chauffert, B.: Delaude, C.: Lacaille-Dubois, M. A. J. Not. Prod. 2002, 65, 193.

24. Gonzales, A. G.; Fraga, B. M:- Gonzales, P.; Hemandez, M. G. Phytochemistry 1981, 20, 1919 .

25. Melek, F. R.; Miyase, T.; Abde-Khalik, S. M:; Hetta, M. H.; Mahmoud, I. I. Pintochemistry 2002, 60, 185.

26. Soliman, H. S. M.; Elgamal, M. H. A.; Simon, A.; Tóth, A.; Horvath, G.: Duddeck, H. J. Nat. Prod. 1999, 62, 885.

27. Godevac, D.; Mandic, B.: Vajs, V.: Teševic, V.; Menkovic, N.; Janaćković, P.; Milosavljević, S. Biochent. Syst. Ecol. 2006, 34, 890.

28. Junjun, N:; Gao, H; Surn, B; Wang, Z; Wu, L. Asian J. Trad. Med. 2006, 1,69. 